\title{
A review of current energy systems and green energy potential in Kazakhstan
}

\author{
Marat Karatayev ${ }^{\mathrm{a}}$ and Michèle L. Clarke ${ }^{\mathrm{a}, \mathrm{b}}$ \\ ${ }^{a}$ Energy Technologies Research Institute, University of Nottingham, Nottingham, NG7 2TU, United Kingdom \\ ${ }^{b}$ School of Geography, University of Nottingham, University Park, Nottingham NG7 2RD, United Kingdom
}

\begin{abstract}
Kazakhstan is rich in natural resources including coal, oil, natural gas and uranium and has significant renewable potential from wind, solar, hydro-power and biomass. In spite of this, the country is currently dependent upon fossil fuels for power generation. Coal-fired plants account for $75 \%$ of total power generation leading to concerns over greenhouse gas emissions and impacts on human health and the environment. Recent economic growth in Kazakhstan has driven increased demand for energy services, making the construction of additional generating capacity necessary for enabling sustained economic growth. In this context, renewable energy resources are becoming an increasingly attractive option to help bridge the demand-supply gap and to decrease national greenhouse gas emissions. This study presents an overview of the existing energy system in Kazakhstan and investigates policy drivers for the energy sector. We review existing studies, national reports, energy strategies and plans, to identify and describe key barriers that prevent diffusion of renewable energy technologies in Kazakhstan. We propose potential measures to overcome specific barriers in order to successfully develop a renewable energy sector in Kazakhstan. It is seen that the likely major contributors to replacing fossil fuel based energy services are likely to be wind power and solar energy technologies, with biomass and hydro energy sources likely to play a lesser role. The barriers to development include low electricity tariffs, transmission losses and inefficient technologies, weak regulatory and legal frameworks and a high-risk business environment.
\end{abstract}

\section{Keywords:}

Fossil fuel; Renewable energy; Barriers; Measures to overcome barriers; Kazakhstan. 


\section{Introduction}

Kazakhstan emerged from the dissolution of the Soviet Union in 1991 and is currently an upper middle income country of around 17.4 million people [1] spread unevenly over an area of 2.7 million $\mathrm{km} 2$ [2] with $47 \%$ of the population living in rural areas [3]. Kazakhstan is located in the centre of the Asian continental land mass and consists of steppe grassland and pastureland in the north, desert and semi-desert in the central and western catchments of the Caspian and Aral Seas and with high mountains in the Tien Shan and Pamir ranges, which are nationally important sources of water, fringing the south of the country. Agricultural land comprises 76.5 million hectares with $61 \%$ permanent pastures and $32 \%$ arable land producing grain and livestock [4]. The climate of Kazakhstan is continental [5], characterized by intensely cold winters with January air temperatures ranging from $18.5{ }^{\circ} \mathrm{C}$, in the north of the country, to $1.8{ }^{\circ} \mathrm{C}$ in the south, and hot summers with July air temperatures ranging from $19.4{ }^{\circ} \mathrm{C}$ in the north to $28.4{ }^{\circ} \mathrm{C}$ in the south [6]. Energy consumption reflects the impact of the challenging continental climate with harsh winters necessitating space heating and hot summers air conditioning, which places an increasing demand on power supplies.

Kazakhstan's economy benefits from its natural resources (particularly oil, gas and uranium), heavy industry (ferrous and non-ferrous metals) and agricultural sectors. The petroleum and mining industries accounted for $33 \%$ of GDP in 2010 and $82 \%$ of exports [7]. GDP increased from 16.9 billion USD in 1999 to 224.4 billion USD in 2013 [8]. Since 2000, the GDP growth rate of Kazakhstan has varied between 6.5 and 9\%, as shown in Fig. 1 [8]. The favourable economic environment and rapid per capita income growth contributed to an impressive reduction in poverty from $47 \%$ of the total population living in poverty in 2001 to $3 \%$ in 2013 [8]. However, in common with many developing countries, rapid economic growth in the past decade has led to a sharp upswing in electricity consumption; power shortages in the winter periods where demand on electric loads has necessitated restrictions on consumption have had an adverse impact on regional economic development [9]. Primary energy consumption has risen from 26.92 Mtoe in 1999 to 82.03 Mtoe in 2013 [9] while total annual power generation has increased from 45 TWh in 1999 to 91 TWh in 2013 as can be seen in Figs. 2 and 3 [10]. The total installed capacity is $19.8 \mathrm{GW}$ [11], while the available capacity is about $15 \mathrm{GW}$ [12] principally due to aging equipment and lack of maintenance [13]. Approximately $10 \%$ of Kazakhstan's power is generated by hydroelectric power stations along the Irtysh River, whilst $90 \%$ is from thermal-powered plants (75\% coal-fired stations and 15\% gas-fired plants), as presented in Figs. 4 and 5 [14]. Renewable sources 
such as wind, solar, small hydro and bioenergy currently contribute less than $1 \%$ of Kazakhstan's energy mix [15] however there is considerable potential in renewable power generation and the government expects the total share of renewable power generation to rise to $11 \%$ by 2030 with $1040 \mathrm{MW}$ of renewable energy capacity by 2020 [11].

$80 \%$ of total electricity is produced in the industrial north by power plants located near coal mines [12] however electricity transmission networks across the country are inefficient with losses during transmission and distribution estimated at approximately $15 \%$ of energy produced, although the actual value may be higher [11]. As presented in Fig. 6, the electricity transmission and distribution system is divided into three networks with two in the north connected to Russia, and one in the south connected to the Unified Energy System of Central Asia [12]. Growth in the demand for electricity is forecast to reach between 120 and 180 TWh by 2030, as depicted in Fig. 7 [16]. Given Kazakhstan's rapid economic development and the associated increasing electricity demand, significant modernisation of existing power facilities in addition to construction of new power generation plants of 20 GW is needed by 2020 [16]. Improving energy efficiency is also important; a recent study demonstrated that improving the efficiency of electricity and heat systems can cut almost one third of electricity and heat consumption in Kazakhstan's residential and commercial sectors at an average cost for end users of about 1 \$GJ [17]. The industrial sector currently accounts for approximately $70 \%$ of the total end-use electricity consumption, with the residential sector $10 \%$, the commercial and service sectors cumulatively $9 \%$, transport $6 \%$ and agriculture $2 \%$ as shown in Fig. 8 [18]. To encourage an increase in efficiency and to cope with the challenging demand-supply situation, the Kazakhstani Government enacted an Efficiency Law in 2012 and in 2013 launched an Energy Efficiency Programme 2020 aimed at reducing the energy intensity of the national economy by $10 \%$ by 2015 and by $25 \%$ by $2020[11]$.

Kazakhstan's energy sector is responsible for carbon dioxide emissions of $275 \mathrm{MtCO} \mathrm{e}$ in 2011 (Fig. 9) with 80\% derived from the energy sector from heat and power generation due to the low efficiency and aging generating plant and network assets [19]. In order to decrease emissions and meet the increasing electricity demand, a decentralised, efficient and environment- friendly energy supply system based on diverse renewable resources is urgently needed [20]. Renewable energy is an important mechanism [21] for achieving sustainable development [22] and Kazakhstan has abundant resources (solar irradiance, wind energy, hydroelectric power, biomass and organic wastes and residues) suggesting that 
adequate utilisation of these resources could complement the country's energy portfolio [15]. Renewable energy also contributes to significant reductions in greenhouse gas emissions [23], local air pollution, and minimises the impact on the natural environment [24].

\section{Conventional energy resources in Kazakhstan}

Kazakhstan possesses significant reserves of oil, gas, coal and uranium. These resources are unevenly distributed across the country and their production, transportation and use has been challenging for grid connectivity [13], the environment [25] and regional geopolitics [26].

\subsection{Coal}

Kazakhstan's coal reserves comprise c. 37 billion tons (4\% of world estimated reserves) [27] of mostly anthracitic and bituminous coals. Mines are located in central Kazakhstan principally in the $2000 \mathrm{~km}^{2}$ Karaganda [28] and $63 \mathrm{~km}^{2}$ Ekibustuz basin coalfields [29] and the sector is said to have enough reserves to last over 100 years [30]. In the east, southeast and southwest of the country, there are smaller deposits of coal, but to date these have been poorly exploited. Coal production is currently $120 \mathrm{Mt}$ of which $97 \mathrm{Mt}(80 \%)$ is consumed domestically for electricity and heat production in thermal power plants with the remaining 22 Mt exported, as shown in Fig. 10 [27]. The Government of Kazakhstan plans to increase coal production from $120 \mathrm{Mt}$ in 2010 to almost $200 \mathrm{Mt}$ by 2030 [31]. Coal is used in coalfired boilers for drying coal, heating mine facilities and ventilation air [32], production of coke for industrial use and in thermal plants for heat and power. Kazakhstan coal is predominantly high ash and also polluting since thermal power plants are not routinely fitted with sulphur and nitrogen oxide flue gas scrubbers [30]. Coal-bed methane and coal-mine methane have potential to be captured and used as a fuel and a pilot plant in the Lenina mine in the Karaganda basin has been developed to generate $1.4 \mathrm{MW}$ of electricity from coal-mine methane [33] and this is an area of potential future growth. Technologies such as carbon capture and storage [34] and underground coal gasification are not currently planned in Kazakhstan.

\subsection{Oil}

Kazakhstan has proven on-shore oil reserves in the west of the country which will enable oil extraction for over 30 years [27], estimated at 30.0 billion barrels (3.9 billion tons) of oil [35] representing 1.8\% of global reserves [36]. At the current time, Kazakhstan has 172 oil and 42 gas condensate fields around the Caspian Sea with total production in 2013 at 81.8 million tons [35]. There are three major oil refineries at Pavlodar, Atyrau and Shymkent 
mostly handling domestic oil [36]. Over $50 \%$ of oil production derives from the large Tengiz, Kashagan and Karachaganak Fields and approximately $85 \%$ of all the oil produced in Kazakhstan is intended for export, as presented in Fig. 11 [35]. However Kazakhstan is a landlocked country and transportation costs are high [37] and the lack of export routes presents a potential bottleneck for Kazakhstan's development plans [38]. At present Kazakhstan exports oil via pipelines, tankers and railways to Russia, the Mediterranean coast of Turkey via Azerbaijan and Georgia and to China with the main routes being: (i) the Tengiz-Novorossiysk pipeline linking the Tengiz Oil Field via the Caspian Pipeline Consortium's $1510 \mathrm{~km}$ pipe to Russia's oil terminal in the Black Sea coast; (ii) the Kazakhstan Caspian Transportation System which consists of three segments (a) the Yeskene-Kuryk pipeline which connects Tengiz and Kashagan oil fields with Kuryk on the Caspian Sea (b) where a system of oil tankers and oil terminals are used to transport the oil across the Caspian to Baku in Azerbaijan (c) where the oil can be moved via the BakuTbilisi-Ceyhan pipeline through Georgia and Turkey to the port of Ceyhan on the southeastern Mediterranean coast; (iii) the $2228 \mathrm{~km}$ Kazakhstan-China pipeline which connects Atyrau to Alashankou in the Xinjiang Uigher Autonomous Province in NW China. In common with natural gas, control of oil export routes provides significant influence over the security and political outcomes and policies of the Caspian states [37] and other neighbouring countries [38] and thus geostrategic power, and Kazakhstan's very ambitious oil export plans heavily rely on viable routes to enable export growth [39].

According to the 2010-2014 'National Program of Forced Industrial and Innovative Development', Kazakhstan's government envisages production will increase to approximately 3.8 million barrels per day by 2020 [11] future development of the domestic oil sector depends on developing the Kazakh sector of the Caspian Sea, where forecasted reserves are expected to last for over 50-60 year [27].

\subsection{Natural gas}

Kazakhstan's proven natural gas reserves comprise around 1.3 trillion $\mathrm{m} 3$ [36] located in the west of the country in oil, oil-gas, and gas condensate fields [7] and it has been estimated that reserves will last 75 years [27]. Natural gas (NG) and associated petroleum gas (APG) production in 2013 totalled 42.3 billion $\mathrm{m} 3$, up 5.5\% year-on-year, of which 22.8 billion $\mathrm{m} 3$ were produced as marketable gas (Fig. 12) [40]. Kazakhstan's gas reserves are dominated by APG, meaning that the gas is produced with oil and for this reason, several Kazakhstan oil and gas fields including the large Karachaganak field re-inject significant quantities to 
enhance oil recovery [41]. Natural gas production in 2013 was estimated at 18.48 billion $\mathrm{m} 3$ [40] and combined NG and APG production is expected to rise to 45 billion $\mathrm{m} 3$ by the end of 2015 [27]. However there is a lack of proper infrastructure linking the demand centres to production. In 2013 it was announced that Kazakhstan's Line C Gas Pipeline would connect to the Asia Gas Pipeline LLP (AGP) to power the flow of natural gas through part of the vast $1833 \mathrm{~km}$ long Central Asia-China Gas Pipeline network connecting Turkmenistan, Uzbekistan and Kazakhstan to China transporting 55 billion $\mathrm{m} 3$ of gas each year to China by 2016 [42]; this pipeline connection will also meet some domestic needs (Fig. 13) [41]. At present Kazakhstan is not contributing significantly to the Nabucco gas pipeline which connects the Caspian Sea fuel producing countries of Azerbaijan and Turkmenistan to the European natural gas grid via Turkey [43]. The Nabucco pipeline can be seen as a geopolitical initiative from Europe in response to the impression that Russia uses natural gas as a political weapon [44] causing concerns over energy security [43]; for Kazakhstan this may provide a useful future export market

\subsection{Uranium}

Kazakhstan is the world's leading uranium producer. It holds $15 \%$ of the world's uranium resources with current production at $22,548 \mathrm{t}$ per year (Fig. 14) comprising $38 \%$ of the global total [45]; $90 \%$ of the total uranium production is currently exported [46]. Kazakhstan's sole nuclear power plant, the 90-MW Mangyshlak fast reactor at Aktau was shut down in April 1999 after 27 years of operation however a cooperation deal with Russia on commissioning a new nuclear power station was signed in May 2014 [45].

\section{Renewable energy resources and potential in Kazakhstan}

Despite an energy mix dominated by fossil fuels there is an increasing interest in renewable alternatives due to their environmental sustainability and economic development potential [47].

\subsection{Hydro Power}

Hydropower accounts for approximately 13\% percent of Kazakhstan's total generating capacity delivering around 7.78 TWh from 15 large (450 MW) hydropower stations [7] with a total capacity of $2.248 \mathrm{GW}$ [48]. Large hydro power plants comprise the Bukhtyrma (750 MW), Shulbinsk (702 MW) and Ust-Kamenogorsk (315 MW) plants on the Irtysh river, the Kapshagai (364 MW) plant on the Ili River, the Moinak (300 MW) plant on the Charyn river and the Shardarinskaya (104 MW) plant on the Syrdarya River [49]. Small (1-10 MW) and 
medium-scale (10-50 MW) hydropower projects have become more popular because of their low cost, reliability and apparent environmental friendliness [50]. There are seven small hydropower plants (o10 MW), with a total installed capacity of $78 \mathrm{MW}$ and an estimated potential of $13 \mathrm{TWh}$, spanning east and south Kazakhstan, Zhambyl and Almaty provinces as can be seen Table 1 [51].

\subsection{Wind Power}

Kazakhstan's steppe geography makes it suitable for wind energy applications and the estimated potential of wind energy that can be economically developed is about $760 \mathrm{GW}$ [52]. About $50 \%$ of Kazakhstan's territory has average wind speeds suitable for energy generation $(4-6 \mathrm{~m} / \mathrm{s})$ with the strongest potential in the Caspian Sea, central and northern regions. The wind potential of Kazakhstan can be seen in Fig. 15 (note: the areas with highest potential are found in the central and northern regions).

The most promising individual sites are in the Almaty region in the Djungar (Dzhumgarian) Gates, $600 \mathrm{~km}$ northeast of Almaty close to the Xinjiang border and the Chylyk Corridor 100 $\mathrm{km}$ east of Almaty. Wind potentials of $525 \mathrm{Wm} 2$ in the Djungar Gates and $240 \mathrm{Wm} 2$ in the Chylyk corridor have been estimated with power production from wind turbines potentially achieving $4400 \mathrm{~kW} / \mathrm{h} / \mathrm{MW}$ and $3200 \mathrm{~kW} / \mathrm{h} / \mathrm{MW}$ respectively [54]. Other sites with potential are shown in Table 2. Construction of the first wind plant in Kazakhstan is underway at Yerementau in the Akmola region with twenty two FWT2000 2 MW turbines delivering an installed capacity of $45 \mathrm{MW}$ and a generating capacity of $172.2 \mathrm{kWh}$ [51].

\subsection{Solar energy}

Kazakhstan has areas with high insolation that could be suitable for solar power, particularly in the south of the country, receiving between 2200 and $3000 \mathrm{~h}$ of sunlight per year, which equals $1200-1700 \mathrm{~kW} / \mathrm{m} 2$ annually [51]. The mean annual solar radiation in Kazakhstan can be seen in Fig. 16 (note: the southern region shows the most concentrated solar activity). Both concentrated solar thermal and solar photovoltaic (PV) have potential. There is a $2 \mathrm{MW}$ solar PV plant near Almaty and six solar PV plants are currently under construction in the Zhambyl province of southern Kazakhstan with a combined capacity of 300 MW [55]. In addition to solar PV, concentrated solar thermal is advantageous given it does not require water for operation so can be used in desert and semi-desert areas, the materials (steel, glass, and concrete) are domestically produced in Kazakhstan and readily available, and solar thermal plants store energy in the form of heat, which is far more efficient than the batteries 
used in PV systems and allows electricity to be produced on demand, even after the sun has set, enabling both base and peak loads to be met [56]. There are no current plans to install a concentrated solar thermal plant although the government plans to create $1.04 \mathrm{GW}$ of renewable energy capacity by 2020 [55].

\subsection{Bioenergy}

Kazakhstan has 76.5 Mha agricultural land, 10 Mha forest and 185 Mha steppe grasslands providing abundant biomass wastes and residues which have the potential to generate a range of bioenergy services [57]. Kazakhstan produces and exports crops such as wheat (winter and spring), rye (winter), maize (for grain), barley (winter and spring), oats, millet, buckwheat, rice and pulses, with an average grain yield of 17.5-20 Mt, which equates to roughly 12-14 Mt of biomass wastes [2]. Biomass wastes are currently poorly exploited and only $10 \%$ of the total volume of the residues is used, mostly as a feed additive for livestock; the proportion of rural households using biomass cookstoves for cooking and heating is currently unknown. Organic wastes are also a potential source of energy and at least 400,000 households are known to keep cattle, horses and sheep [7]. It has been estimated that electricity generation potential in Kazakhstan from biomass is 35 billion kWh per year and heat generation potential is 44 million Gcal per year [58]. Various external funding agencies (UNDP, GEF, HIVOS Foundation) have supported the development of biogas initiatives including the Biogas Training Centre at the Eco-museum in Karanga (2002-2003) and the 'Azure Flame' Central Kazakhstan Biogas Education Centre (2004-2005) however despite this promotion there is only one large scale biogas unit currently in operation in the country which is a $360 \mathrm{kWe}$ biogas plant run at Vostok village in the Kostanai region. The Vostok biogas unit consists of two $2400 \mathrm{~m} 3$ digesters operating with a feedstock of 40 t/day of cow, sheep and camel manure, grain residues and $1 \mathrm{t} /$ day of slaughterhouse waste [59]. The plant was installed in 2011 by Karaman-K Ltd. and Zorg Biogas with an aim of delivering 3 million kWh of electricity annually [59].

\section{Barriers to renewable energy in Kazakhstan}

In spite of considerable renewable energy potential there are still significant barriers to address including: low electricity tariffs; transmission losses and inefficient technologies; weak regulatory and legal frameworks to stimulate the use of renewable energy in the electricity sector; persistent governmental body reforms; inadequate levels and quality of scientific support; awareness and information barriers; and a high-risk business environment. 


\subsection{Low electricity tariffs}

Overall electricity consumers in Kazakhstan are divided into: (i) large industrial consumers with an installed load of no less than $750 \mathrm{~kW}$; and (ii) the remainder of consumers. Large industrial consumers and regional energy companies buy electricity directly from generators in a wholesale market and pay generation and regulated transmission tariffs. Other energy consumers buy electricity from regulated regional energy companies and pay a distribution system access fee in addition to the generation and transmission tariffs. Residential consumers also pay a value-added tax and a small excise tax. In general, the average enduser electricity price was commonly set to below cost-recovery levels and was approximately 2.3 US cents per kWh with a maximum level of $3.5 \mathrm{US}$ cents per $\mathrm{kWh}$ in certain parts of the country [12]. The main reason for such low electricity prices is an abundance of inexpensive domestic coal and the continued operation of older, Soviet-era, power plants for which negative environmental pollution costs, capital cost, and future replacement costs had not been accounted for [52]. Furthermore, there is government concern about the sharp increase in the price of electricity for end-users in Kazakhstan. The government recognises that supporting renewable energy, which is perceived to be more expensive than producing electricity from coal, would lead to higher electricity prices. In Kazakhstan, the State Antimonopoly Agency provides strict monitoring of price increases and only allows for interventions if certain thresholds are exceeded. As for the mid-term perspective, the Government Decree (No. 392) in March of 2009 concerning power tariff levels envisages a wholesale rate of between 3.1 US cents per $\mathrm{kWh}$ and 6.4 US cents per $\mathrm{kWh}$ in 2015 (with up to 10.2 US cents per kWh for final end-users). These increases will not be sufficient to support the development of new renewable energy technology facilities in Kazakhstan and further financial support will be required.

\subsection{Transmission losses and inefficient technologies}

In Kazakhstan, the transmission system is owned and operated by the state-owned Kazakhstan Electricity Grid Operating Company which monitors all the transmission lines with capability from $110 \mathrm{~kW}$ to $1150 \mathrm{~kW}$, along with all the transformers and substations. The electricity transmission and distribution networks across the country are inefficient with losses during transmission and distribution estimated at approximately 15\%. In addition, large parts of Kazakhstan's thermal power plants are obsolete and less efficient than most other national energy systems [17,60]. For instance, a typical $1000 \mathrm{MW}$ coal-fired electric power plant has a net efficiency of $27 \%$ and an electricity generation efficiency of between 
$18 \%$ and $21 \%$ (with a total efficiency of $49 \%-68 \%$ ). The net efficiency of gas fired heating plants in comparison ranges between $60 \%$ and $65 \%$ and an electricity generation efficiency of $24-26 \%$ (a total efficiency $71-81 \%$ ). This low efficiency is due mainly to the wear out of existing stock and losses in the flows.

The problem of losses and the inefficiency of the electric power system need to be appropriately addressed. The availability of most renewable energies and the feasibility for transformation may depend upon the geographical condition of the country; and the point of availability and generation may be far away from the point of consumption, leading to high transmission and distribution losses.

\subsection{Weak regulatory and legal framework}

As a part of the Kyoto Protocol, Kazakhstan has taken on a voluntary obligation to decrease carbon emissions by $15 \%$ by 2020 and $25-30 \%$ by 2050, both compared to levels at 1992 . The 2013 'National Concept for Transition to a Green Economy up to 2050' focuses on transitioning the economy and power sector towards sustainable development and aims to bring the share of renewable energy in electricity generation to $3 \%$ by 2020 rising to $30 \%$ by 2030 and $50 \%$ by 2050, as presented in Figs. 17 and 18 [61]. To meet climate and energy targets, the Government has adopted a number of programmes and strategies including the National Strategy for Accelerated Industrial and Innovative Development, the 2050 National Concept for Transition to a Green Economy, the National Programme of Wind Power Development, the Concept on the Transition of Kazakhstan to Sustainable Development, the Concept for Ecological Safety, the 2030 Electricity Development Program and the 2020 Plan Development of Renewable Energy. The aforementioned programmes and strategies mainly set out Kazakhstan's long-term vision; they do not however provide a specific regulatory framework. In an attempt to provide a regulatory framework for renewable energy services, in 2012, the government adopted a law detailing the support and usage of renewable energy services, defining the responsibilities of the National Committee on Renewable Energy Sources as well as local executive bodies. In addition to this, the government developed and adopted regulations in support of renewable energy including: rules of purchase of electricity from qualified power generating organisations; rules of definition of the nearest point of connection to the grid or thermal networks for renewable energy; rules for monitoring of the use of renewable energy; rules for feasibility study assessments. These rules provide some recommendations, procedures and details not covered explicitly in the aforementioned law.

Significant progress has been achieved in developing national climate and energy 
programmes, and in creating a legal and regulatory framework for renewable energy development. However, as stated in the latest UNDP report, the necessary regulatory and legal instruments such as grid access and construction permits have been missed [52], with international experience showing that a lack of appropriate instruments hinders the adoption of renewable energy technologies [62-64].

\subsection{Risky business environment}

Kazakhstan has made considerable progress towards the establishment of a market economy and the provision of an attractive climate for foreign investment. In the last decade, Kazakhstan has experienced strong economic growth, with annual GDP increases of nearly 10\%. In 2011, GDP growth was 7.5\% [1], while in 2013, the World Bank 'Doing Business' report ranked Kazakhstan 49th out of 185 countries- a very respectable result. However, the same report consistently ranked Kazakhstan very low in three areas that are important to renewable energy platform development. Kazakhstan is ranked 182nd in the 'Trading Across Borders', 83th in 'Getting Credit' and 155th in the 'Dealing with Construction Permits' subcategories. Such low rankings in areas crucial to the development of renewable energy will, undoubtedly, have significantly negative impacts on national and especially international investors. Furthermore, political corruption creates a large degree of risk for the renewable energy sector [65]. In 2013, Transparency International's 'Corruption Perceptions Index' ranked Kazakhstan as the country with the highest perceived levels of corruption [66]. Most government indicators for Kazakhstan including accountability, effectiveness, regulatory quality, rule of law, and control of corruption have been notably negative. Such factors make the prospect of investing in renewable energy projects in Kazakhstan prohibitively risky.

\section{Measures to overcome barriers in Kazakhstan}

In order to successfully adopt renewable energy technologies, national governments have to utilise a wide range of available policy instruments, including specific renewable energy plans at national, local and sectorial levels, new regulations and standards, research and development programmes, and public information campaigns.

\subsection{Guaranteed markets}

To address the problem of low electricity tariffs, a comprehensive range of policy options including feed-in-tariffs, a renewable portfolio standard, a mandatory market share policy, and green certificates have to be established. These are common policy options used in renewable energy market support which have been successfully implemented in other 
countries [67]. For example, the electricity feed-in law in Germany, in the 1990s, set a fixed price for utility purchases of renewable energy. According to German electricity feed-in law, renewable energy producers could sell their power to utilities at $90 \%$ of the retail market price with the utilities obligated to purchase the power. As a result, the German feed-in law led to a rapid increase in installed capacity and electricity production from renewable energy systems as well as to the development of commercial renewable energy markets. In the context of Kazakhstan, the government has closely worked with EBDR, UNDP and GEF to establish a fixed feed-in tariff for a long-term period. According to the latest government proposals, the feed-in tariff for electricity produced by renewable energy is set at a minimum 15 US cents per kWh [20]. Although the government has drafted a feed-in tariff for the support of renewable energy, it will need to be periodically revised.

\subsection{Competitive regulatory and legal framework}

Experience in some countries with a high penetration of renewable energy demonstrates that even if well-designed renewable energy support programmes are in place, arduous bureaucratic procedures and administrative hurdles and difficulties in accessing the electricity grid can prevent rapid market development [68]. Without the creation of a clear and comprehensive legal and regulatory framework renewable energy generation technologies will be condemned to remain a small niche market operation. Therefore, a key purpose of the development and adoption of a specific legal and regulatory frameworks is to reduce technical, legal, economic, financial and administrative barriers. Within a regulatory framework preferential access to the grid in all aspects (grid connection, grid usage and grid expansion) has to be guaranteed so that the incumbent energy industry is deprived of the opportunity to deny or delay grid access for renewable energy providers with smooth bureaucratic application procedures also ensured. For example, clear and simple regulations concerning the licences required for the building and operation of renewable energy systems are of a crucial necessity and all rules should be as simple as possible. Ideally, one comprehensive renewable energy law should contain all the important provisions.

In Kazakhstan, a new law on Green Economy is currently at the approval stage in the National Parliament. The law contains all previously adopted renewable energy rules and provides a new regulatory framework. In particular, the law guarantees grid connection, grid usage and grid expansion for renewable energy producers. It requires the regional power grid companies to purchase in full all of the electrical energy produced by renewable energy 
providers.. Moreover, such energy-producing organisations are relieved of any duties to pay for energy transmission services. However, further serious legislative work is required to promote the development of renewable energy supply. In particular, it is necessary to determine whether there will be tax and customs incentives within the implementation of renewable energy projects.

\subsection{Policy reforms to promote energy efficiency}

Recent studies on energy efficiency in Kazakhstan show that both the electricity and heat sectors have strong potential for improving their levels of energy efficiency $[17,60]$. Currently, the Ministry of Industry and New Technologies is proposing a specific program 'On Energy Saving', which considers significant liberalisation measures including the restructuring of the energy sector, thereby opening up the sector to introduce more competition and removing other controls that hinder growth. The basic purpose of liberalisation is to increase efficiency of the entire energy sector by facilitating market competition. Evidence from Argentina shows that after implementing a liberalisation reform and making management and maintenance more efficient, electric losses from distribution and transmission activities reduced from $27 \%$ to $10 \%$ during the last decade [69]. Privatelyowned electric power companies have higher levels of efficiencies than state-owned plants, so the initial impact of liberalisation will be unfavourable to new renewable energy generation due to an increase in competitiveness. However, over time, a liberalised energy market will provide a better environment for the healthy growth of renewable energy generation.

\subsection{Government investments}

Huge investments are needed to modernise, decarbonise and replace the old and unreliable power system in Kazakhstan. According to the project '2030 Development of Kazakhstan's Power sector', the total capital investment required in generation capacity is about 3-4 billion US dollars annually [12]. In countries where governments are major players in the power sector, they may also be the main investors using specialised state-owned funds and newly created state agencies for development of renewable energy provision. For example, in 2001, China's government launched a renewable energy-based rural electrification programme known as 'Sending Electricity to Townships' [21]. The programme electrified more than 1000 townships in nine western provinces in China, bringing power to nearly one million people and providing the basis for rural economic development. Within this programme, the government provided 220 million U.S. dollars to subsidise the capital costs of equipment. 


\section{Conclusions}

Kazakhstan has abundant natural resources. The country has substantial quantities of petroleum deposits, natural gas, coal and uranium. Rapid economic growth in the past decade has led to an increase in primary energy consumption and a growing electricity demand. The domestic energy sector of Kazakhstan remains heavily dependent on coal to deliver its power and electricity needs. Increasing energy consumption coupled with concerns about environmental pollution is driving a new interest in renewable alternatives. Kazakhstan has the necessary natural, climatic, and economic conditions to develop sustainable bioenergy solutions. Wind power, small and medium-scale hydro and solar technologies also have significant potential. Given that $47 \%$ of the population is rural, smallscale renewable decentralised energy systems offer good opportunities to transition away from a dependence on fossil fuels and to enable further economic growth. However, broad and flexible regulatory support mechanisms are required to encourage adoption of these technologies. The long-term feed-in tariff must be approved with grid access guaranteed. To improve the efficiency of the Kazakhstani power system, the decentralisation of the power sector and other reforms must be undertaken. Innovative research and development programmes for the adoption of renewable energy systems should be put in place. Taking into account existing information barriers, programmes that bring about awareness to a wide audience including individual consumers, businesses and industries are required. In conclusion, international experience shows that development of renewable energy requires significant investment. In this context, the government may become a key investor through a specialised state-owned fund and other state agencies.

\section{Acknowledgements}

This work has been funded by Newton Al-Farabi Fund award 'The Potential Application of Renewable Energy for Rural Energy Services and Electrification in Kazakhstan' and we would like to thank the British Council for their support. MLC also acknowledges funding support for this work from the Engineering and Physical Sciences Research Council EP/J000376/1 Rural Hybrid Energy Enterprise Systems and EP/M029212/1 Newton Fund: Novel strategies for the recovery of deforested and degraded landscapes in the Amazon region: sustainable energy-food-water services. 


\section{References}

1. WB. Kazakhstan Partnership Programme Snapshot. World Bank 2013. Available at: www.worldbank.org

2. FAO. General summary for the countries of the former Soviet Union. Food and Agriculture Organization of the United Nations 2013. Available at: www.fao.org

3. Agency of statistics of the Republic of Kazakhstan. Demography and Migration: An outlook for 1991-2013. Available at: www.stat.gov.kz

4. USDA. Kazakhstan: Agriculture Overview. U.S. Department of Agriculture 2013. Available at: www.pecad.fas.usda.gov

5. Mizina SV, Smith JB, Gossen E, Speiker KF, Witkowski SL. An evaluation of adaptation options for climate change impacts on agriculture in Kazakhstan. Mitigation and Adaption Strategy Global Change 1999; 4: 25-41.

6. Pilifosova OV, Eserkepova IB, Dolgih SA. Regional climate change scenarios under global warming in Kazakhstan. Climatic Change 1997; 36: 23-40.

7. NRGI. Kazakhstan report. Natural Resource Governance Institute 2014. Available at: Www.resourcegovernance.org

8. Agency of statistics of the Republic of Kazakhstan. Population and Microeconomic outlook: 1991-2013. Available at: www.stat.gov.kz

9. Enerdata. Global Energy Statistical Yearbook 2013. Available at: Www.yearbook.enerdata.net

10. EBRD. Electricity market in Kazakhstan. European Bank for Reconstruction and Development 2013. Available at: www.ebrd.com

11. Kadrzhanova A. Kazakhstan: Power Generation and Distribution Industry. US Department of Commerce report 2013. Available at: www.government.kz

12. KEGOC. Regular review of electric balance and energy efficiency in Kazakhstan. Kazakhstan Electricity Grid Operating Company 2013. Available at: www.kegoc.kz

13. Atakhanova Z, Howie P. Electricity demand in Kazakhstan. Energy Policy 2007; 35: 3729-3743.

14. INOGATE. National Energy Statistics Action Plan for the Republic of Kazakhstan. INOGATE Programme: Technical Secretariat and Integrated Programme in support of the Baku Initiative and the Eastern Partnership Energy Objectives 2014. Available at: $\underline{w w w . i n o g a t e . o r g}$

15. REEEP. Kazakhstan: policy and regulatory overviews. Renewable Energy and Energy Efficiency Partnership 2014. Available at: $\underline{w w w . r e e g l e . i n f o}$ 
16. KIER. Spatial organization of territory in Kazakhstan for the period until 2030. Kazakh Institute of Economic Research 2014. Available at: www.economy.kz

17. Sabrassov Y, Kerimray A, Tokmurzin D, Tosato G, de Miglio R. Electricity and heating system in Kazakhstan: exploring energy efficiency improvement paths. Energy Policy 2013; 60: 431-444.

18. EIA. Kazakhstan country analysis brief. Washington DC: Energy Information Administration 2013. Available at: $\underline{w w w . e i a . o r g}$

19. UNFCCC. Report of the individual review of the inventory submission of Kazakhstan. United Nations Framework Convention on Climate Change 2013. Available at: $\underline{w w w . u n f c c c . i n t}$

20. MINT. Presentation Ministry of Industry and New Technology (A. Isekeshev) at Regional conference on renewable energy development in the countries of Central Asia and CIS. Development of power industry of Republic of Kazakhstan for 2020. Ministry of Industry and New Technology Republic of Kazakhstan, 2011. Available at: www.mint.gov.kz

21. REN21. Renewables 2014 global status report. Renewable energy policy network 2013. Available at: www.ren21.net

22. Dincer I. Renewable energy and sustainable development: a crucial review. Renewable Sustainable Energy Review 2000; 4: 157-175.

23. Panwar NL, Kaushik SC, Kothari S. Role of renewable energy sources in environmental protection: A review. Renewable Sustainable Energy Review 2011; 15: $1513-1524$.

24. Jacobson MZ. Review of solutions to global warming, air pollution, and energy security. Energy \& Environmental Science 2009; 2: 148-173.

25. Dahl C, Kuralbayeva K. Energy and the environment in Kazakhstan. Energy Policy 2001; 29: 429-440.

26. Garrison JA, Abdurahmanov A. Explaining the Central Asia Energy Game: complex interdependence and how small states influence their big neighbours. Asian Perspective 2011; 35: 381-405.

27. KAZENERGY. National Energy Report. Kazakhstan Association of Oil-Gas and Energy Organizations 2013. Available at: http://kazenergy.com/

28. USEPA. ArcelorMittal coal mines. Karaganda coal basin report. U.S. Environmental Protection Agency 2013. Available at: www.epa.gov

29. Umarhajieva NS, Mustafin RK. Central Kazakhstan coal fields potential for development of coal-bed methane projects. Available at: www.coalinfo.net 
30. Oprisan M. Prospects for coal and clean coal technologies in Kazakhstan. IEA Clean Coal Centre. Available at: www.iea.org

31. Vorotnikov V. Kazakhstan Prepares to Grow Coal Production. Available at: www.coalage.com

32. Bibler CJ, Marshall JS, Pilcher RC. Status of world-wide coal mine methane emissions and use. International Journal Coal Geology 1998; 35: 283-310.

33. Kazakhstan coal pioneers methane power project. Available at: www.corporate.arcelormittal.com

34. Katyshev S. UN Expert Group Meeting on Carbon Dioxide Capture and Storage and Sustainable Development. Available at: www.undp.kz

35. OECD. Statistical Yearbook 'Kazakhstan in 2012'. Organisation for Economic Cooperation and Development, 2013. Available at: www.oecd.org

36. BP Statistical Review of World Energy. Available at: www.bp.com

37. Shaffer B. Caspian energy phase II: beyond 2005. Energy Policy 2010; 38: 72097215.

38. Irek P. The role of oil and gas in Kazakhstan's foreign policy: looking East or West? Europe-Asia Studies 2007; 59: 1179-1199.

39. Babali T. Prospects of export routes for Kashagan oil. Energy Policy 2009; 37: 12981308.

40. Agency on Statistics of the Republic of Kazakhstan. Fuel and Energy Balance of Kazakhstan. Available at: www.stat.gov.kz

41. USDE. Kazakhstan: Energy Information Report. U.S. Department of Energy, 2013. Available at: www.iea.org

42. Rolls Royce. Rolls-Royce wins US\$175m contract to power Kazakhstan-China natural gas pipeline. 10 September 2013. Available at: $\underline{w w w . r o l l s-r o y c e . c o m / n e w s ~}$

43. Erdogdu E. Bypassing Russia: Nabucco project and its implications for energy security. Renewable and Sustainable Energy Reviews 2010; 14: 2936-2945.

44. Bilgin M. Geopolitics of European natural gas demand: supplies from Russia, Caspian and the Middle East. Energy Policy 2009; 37: 4482-4492.

45. WNA. Russia helps Kazakh nuclear power plants. World Nuclear Association 2014. Available at: www.world-nuclear-news.org

46. WNA. Kazakhstan: Facts and figures. World Nuclear Association 2014. London. UK. Available at: www.world-nuclear.org

47. Srebotnik T, Hardi P. Prospects for sustainable bioenergy production in selected former communist countries. Ecological Indicators 2011; 11; 1009-1019. 
48. EBRD. The Low Carbon Transition. European Bank for Reconstruction and Development Report 2011. Available at: $\underline{\text { www.ebrd.com }}$

49. Marinina O. Problems of water resources management in the Republic of Kazakhstan, interrelations of hydro power and water industries. Proceedings of the VI regional workshop Water resources and water use problems in Central Asia and the Caucasus, Institute for Water and Environmental Problems, 109-116. ISBN 9785-9900731-5-9.

50. UNIDO. World Small Hydropower Development Report. United Nations Industrial Development Organization; International Center on Small Hydro Power 2013. Available at: www.smallhydroworld.org

51. BMZ. Renewable Energies in Central Asia. Country Chapter: Republic of Kazakhstan. Germany Federal Ministry for Economic Cooperation and Development 2013. Available at: www.gtz.de

52. UNDP. Lessons learnt from the Kazakhstan: wind power market development initiative. United Nations Development Program Kazakhstan 2011. Available at: www.undp.kz

53. KRIG. National Atlas of Republic of Kazakhstan. Volume 1: Environment and Natural Resources. Kazakhstan Research Institute of Geography, 2013.

54. UNDP-GEF. Prospective of Wind Power Development in Kazakhstan. United Nations Development Program Kazakhstan and Global Environmental Fund 2006. Available at: $\underline{w w w . w i n d e n e r g y . k z}$

55. EY. Renewable Energy Investment Forum in Kazakhstan. Communication from Ernst \& Young 2013. Available at: www.ey.kz

56. Cochran J. Kazakhstan's potential for wind and concentrated solar power. Kazakhstan, Almaty, 2007.

57. Pala C. Abandoned Soviet Farmlands could help offset global warming. Environmental Science Technology 2009; 43 (23): 8685-8707.

58. Energy Partner LLP. Biomass and biogas in Kazakhstan report. Energy Partner LLP 2014. Available at: www.energypartner.kz

59. Zorg Biogas. First biogas plant started energy production in Kazakhstan. Zorg Biogas 2011. Available at: http://zorg-biogas.com

60. Gómez A, Dopazo C, Fueyo N. The causes of the high energy intensity of the Kazakh economy: A characterization of its energy system. Energy 2014; 71: 556568. 
61. NCTGE. National Concept for Transition to a Green Economy up to 2050. Approved by Decree of the President of the Republic of Kazakhstan on May 30, 2013, N 557. Available at: www.strategy2050.kz

62. Kaygusuz K. Energy for sustainable development: A case of developing countries. Renewable and Sustainable Energy Reviews 2012; 16 (2): 1116-1126.

63. Painuly JP. Barriers to renewable energy penetration; a framework for analysis. Renewable Energy 2001; 24: 73-89.

64. Wilkins G. Technology transfer for renewable energy. Overcoming barriers in developing countries. Earthscan Publications Ltd, London. The Royal Institute of International Affairs, 2002.

65. Kaiser MJ, Pulsipher AG. A review of the oil and gas sector in Kazakhstan. Energy Policy 2007; 35: 1300-1314.

66. Transparency International (2013). Corruption Perceptions Index. Available at: www.transparency.org

67. Abolhosseini S, Heshmati A. The main support mechanisms to finance renewable energy development. Renewable and Sustainable Energy Reviews 2014; 40: 876885.

68. OSCE (2009). The importance of the legal and regulatory framework for the development of renewable energy.

69. Wamukonya N. Power sector reform in developing countries: mismatched agendas. Energy Policy 2003; 31(12): 1273-1289. 


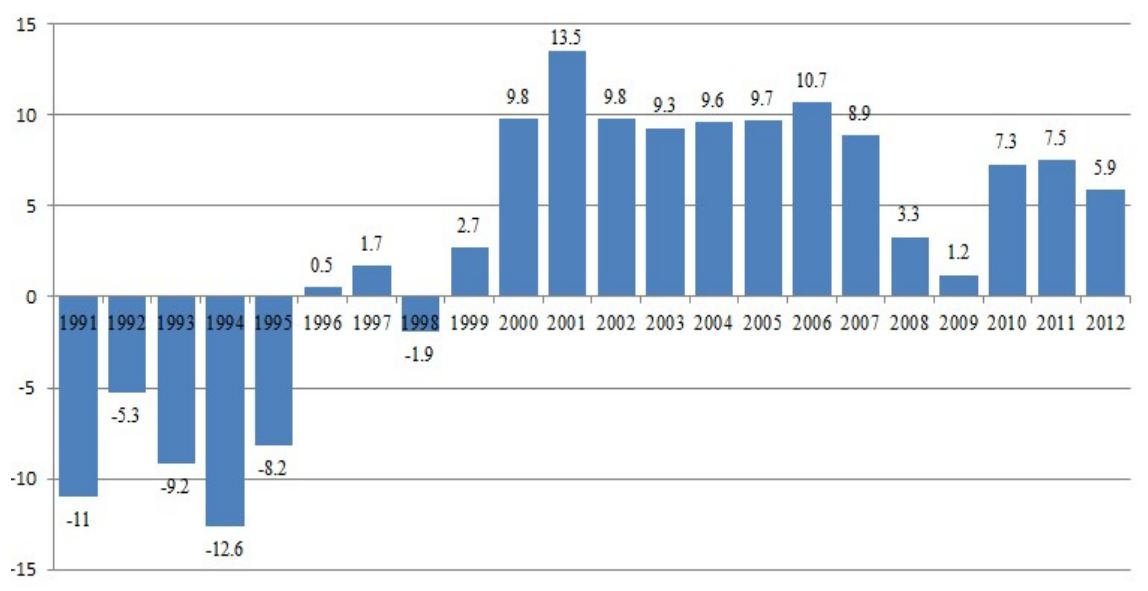

Fig. 1. Kazakhstani GDP growth (annual \%, $1990=100 \%$ ) [8]

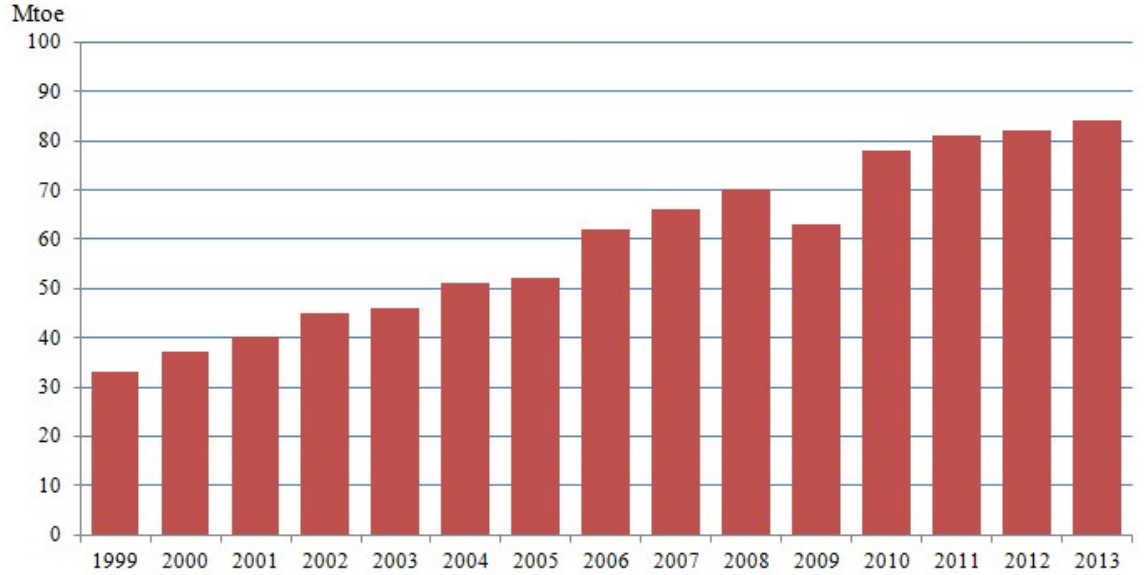

Fig. 2. Primary energy consumption (Mtoe) [9]

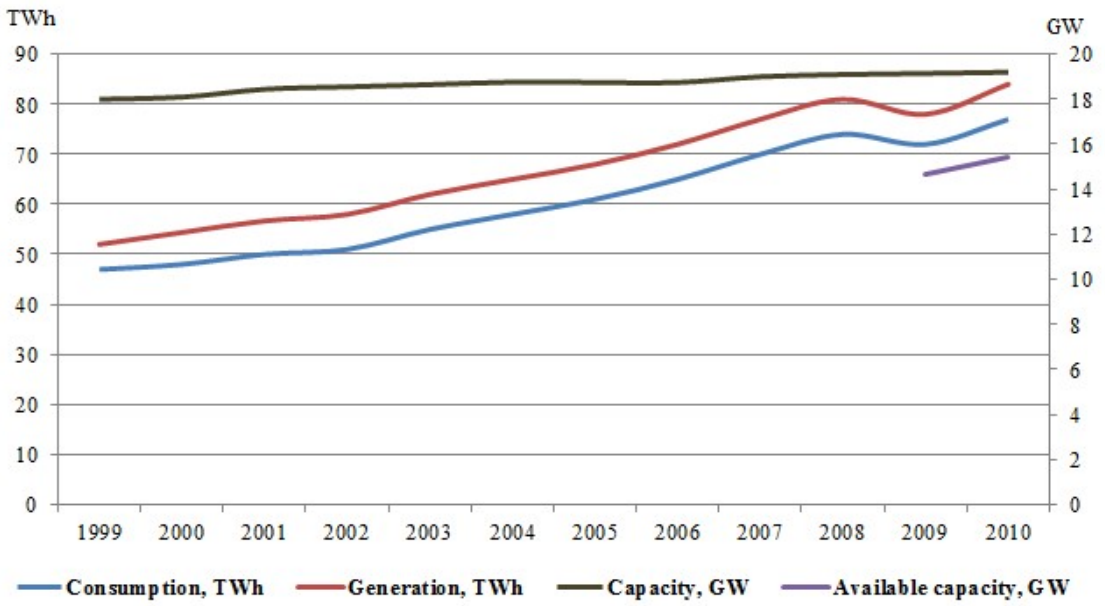

Fig. 3. The growth of the electricity sector in Kazakhstan (TWh) [10] 


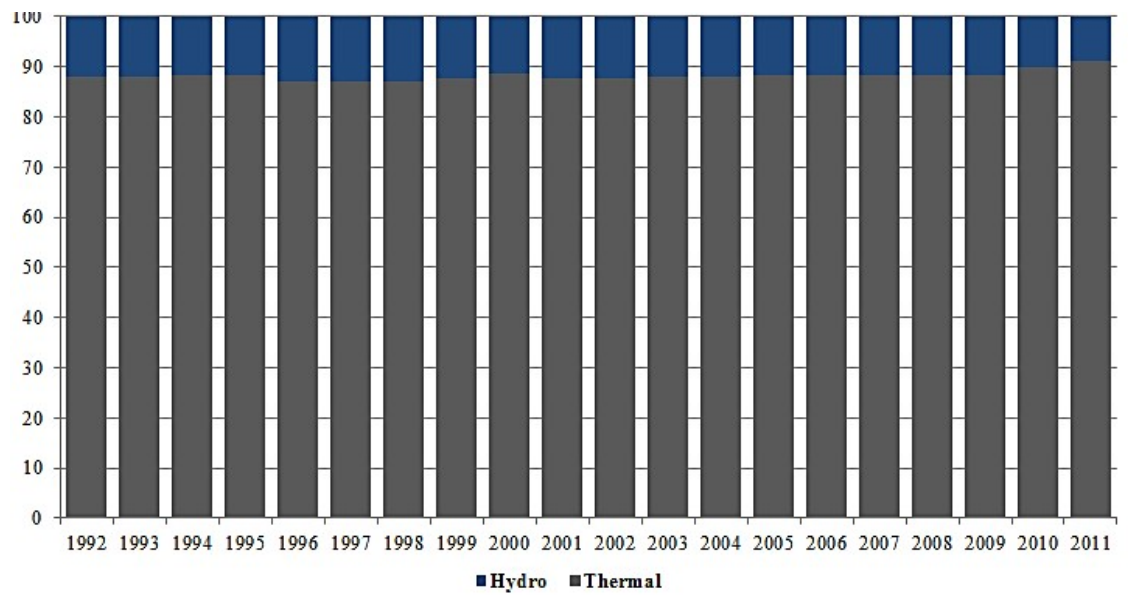

Fig. 4. Electricity generation by fuel type (\%) [14]

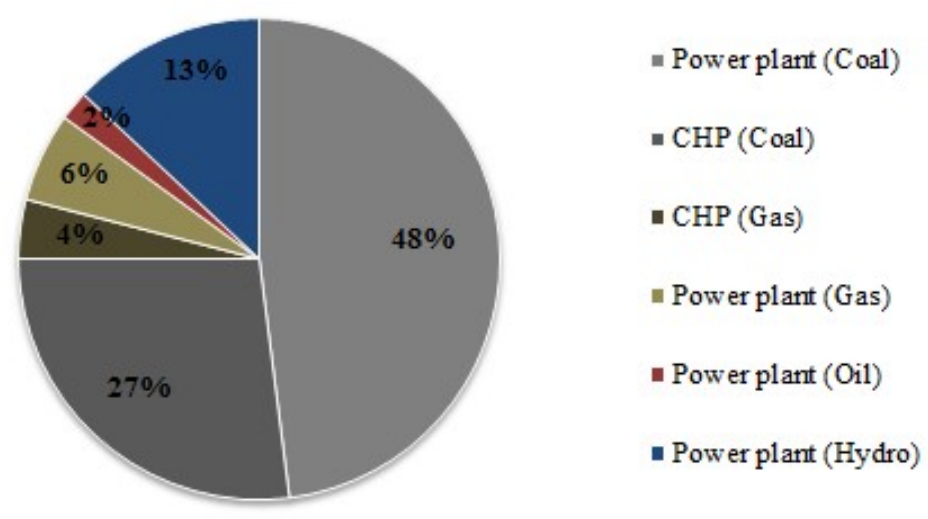

Fig. 5. Kazakhstan's electricity generating capacity (\%) [14] 


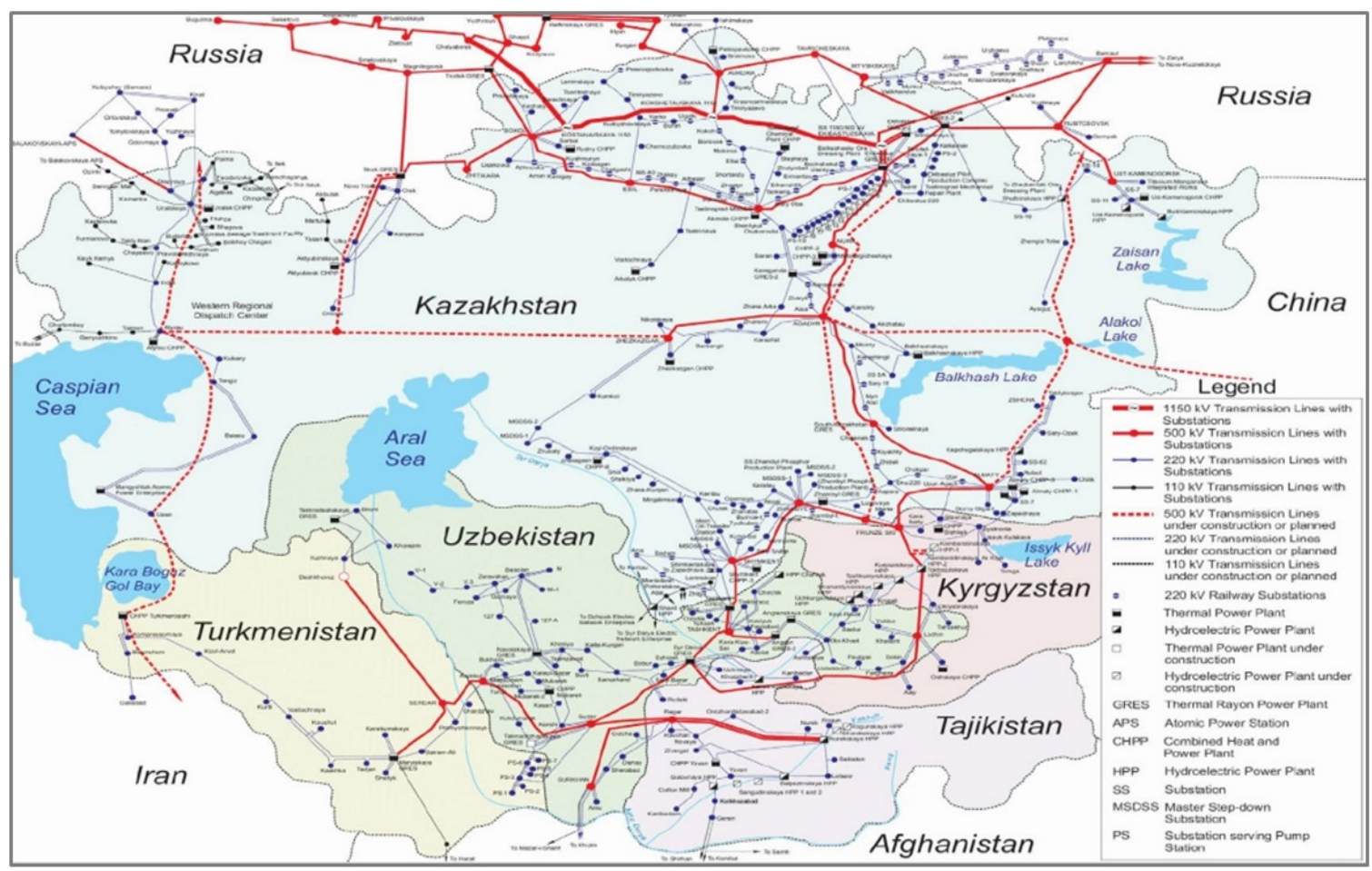

Fig. 6. Electric power transmission networks [12]

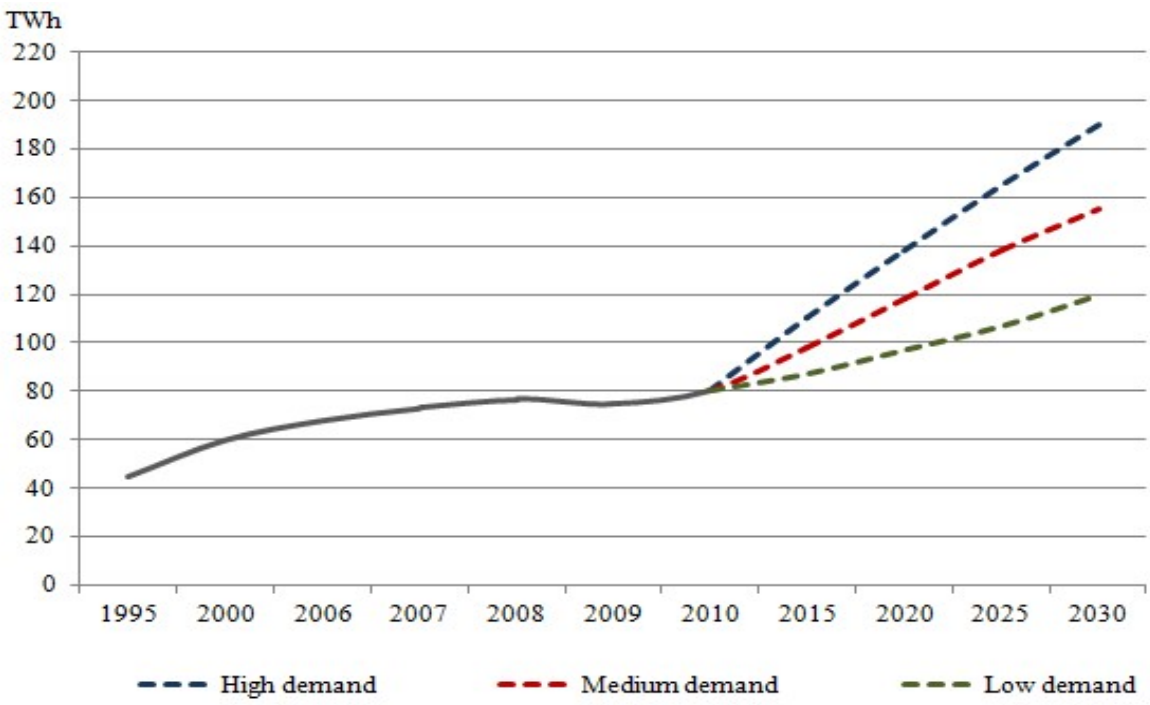

Fig. 7. Forecast of electricity demand in Kazakhstan (TWh) [16] 


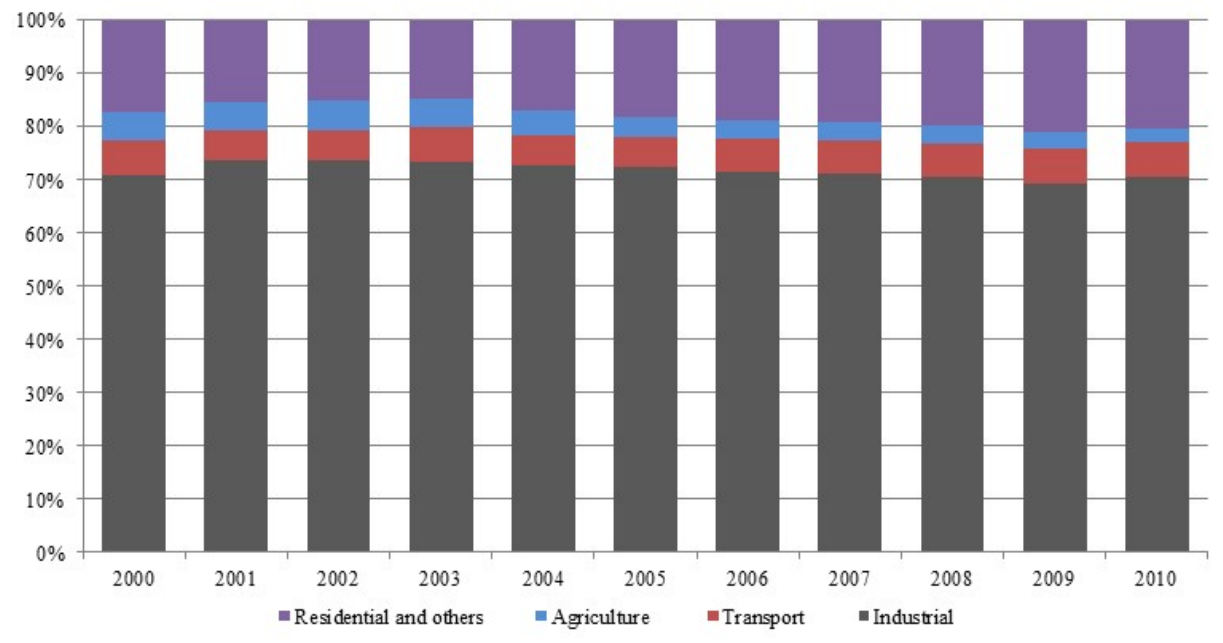

Fig. 8. Final electricity demand by sector (\%) [18]

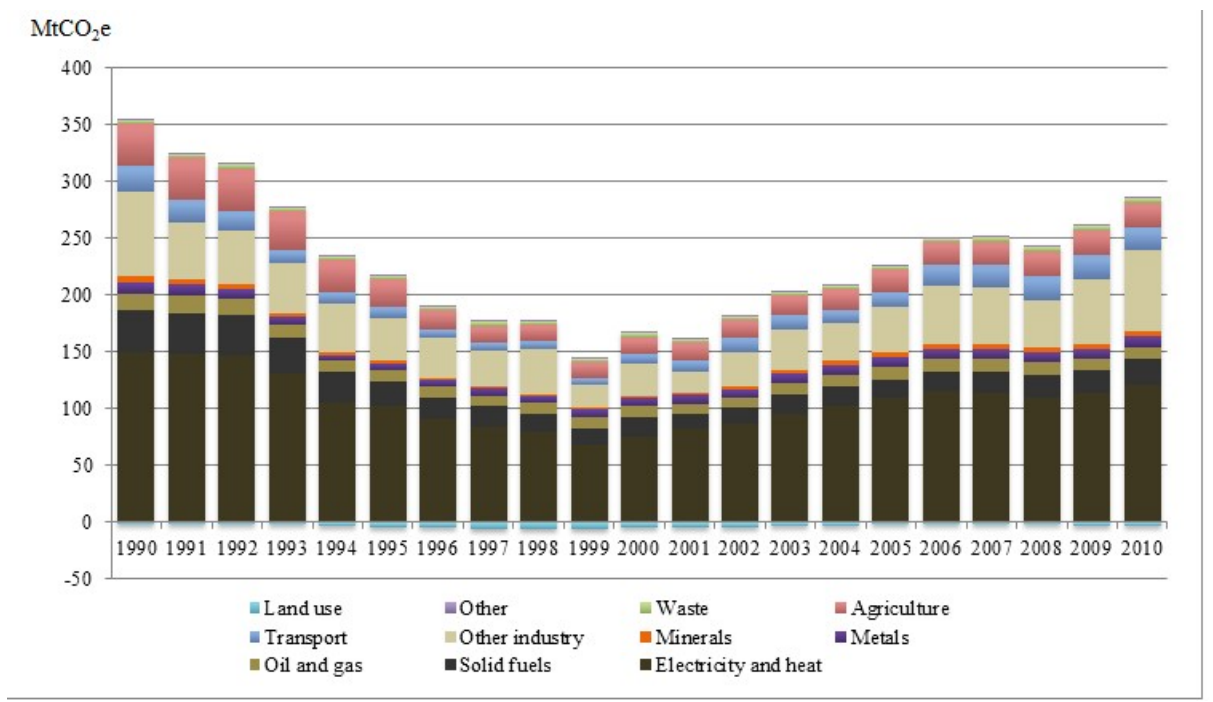

Fig. 9. Total greenhouse gas emissions $\left(\mathrm{MtCO}_{2} \mathrm{e}\right)$ [19] 


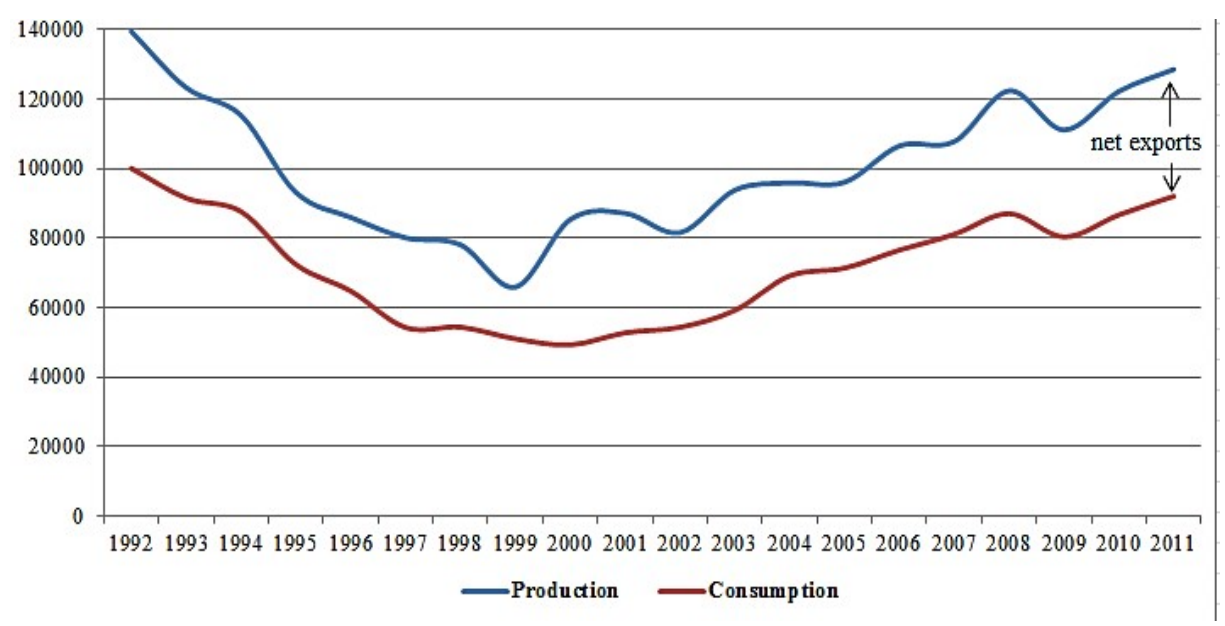

Fig. 10. Coal production and consumption (Kt) [27]

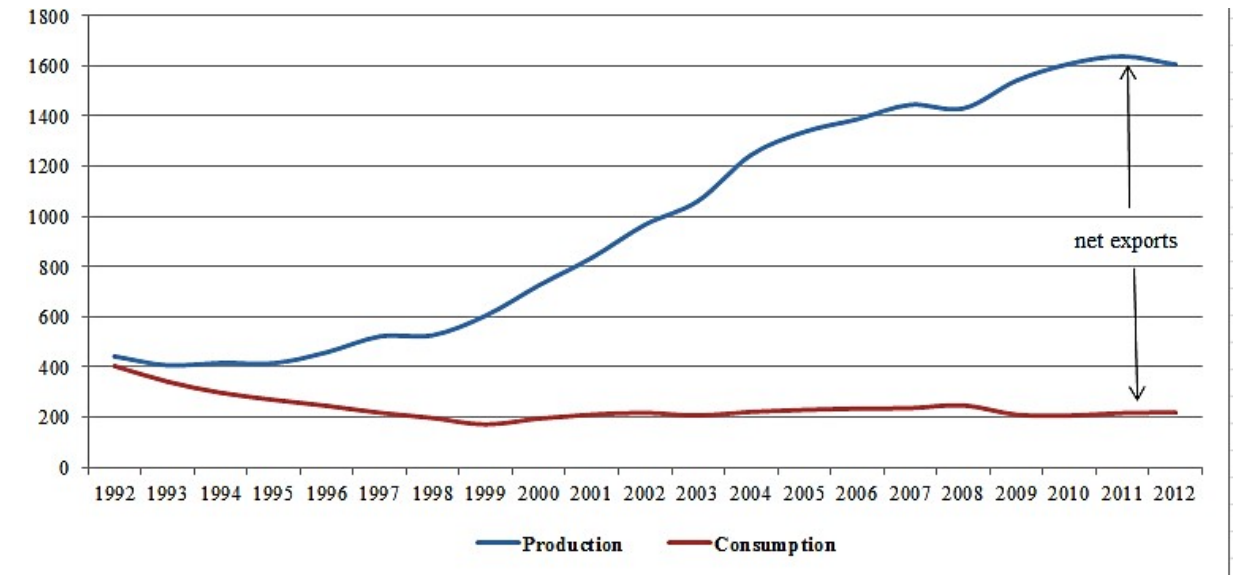

Fig. 11. Production and exports of crude oil (KBOE/d) [35]

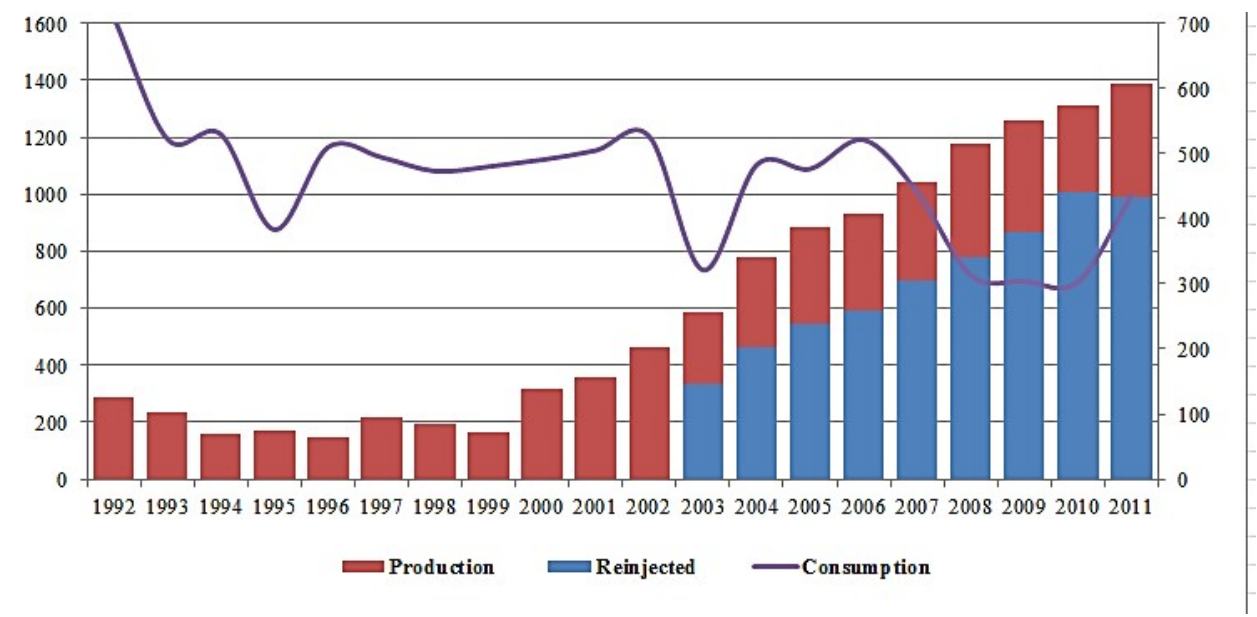

Fig. 12. Natural gas production, consumption and reinjected volumes (BCF) [40] 


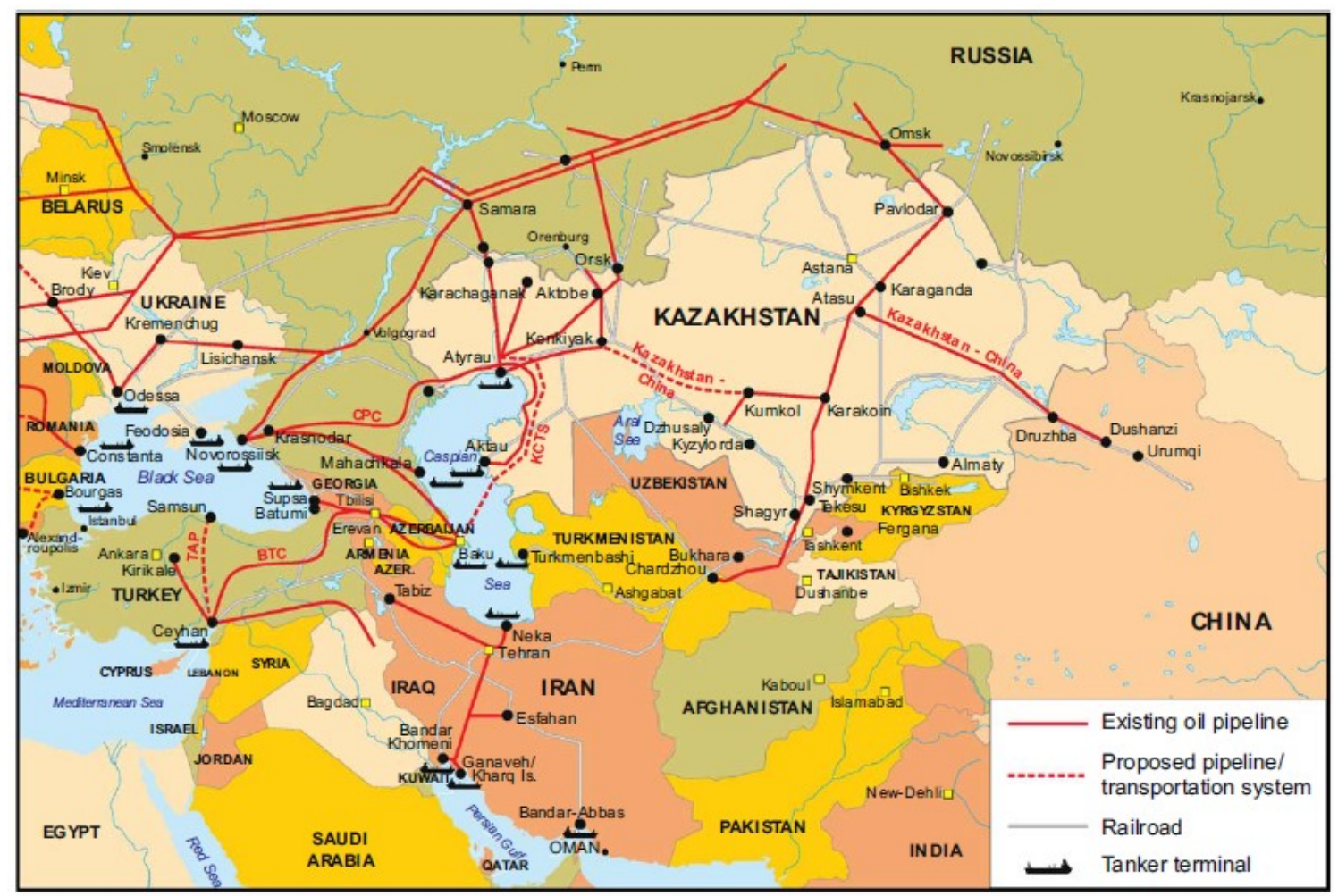

Fig. 13. Pipeline developments in Kazakhstan [41]

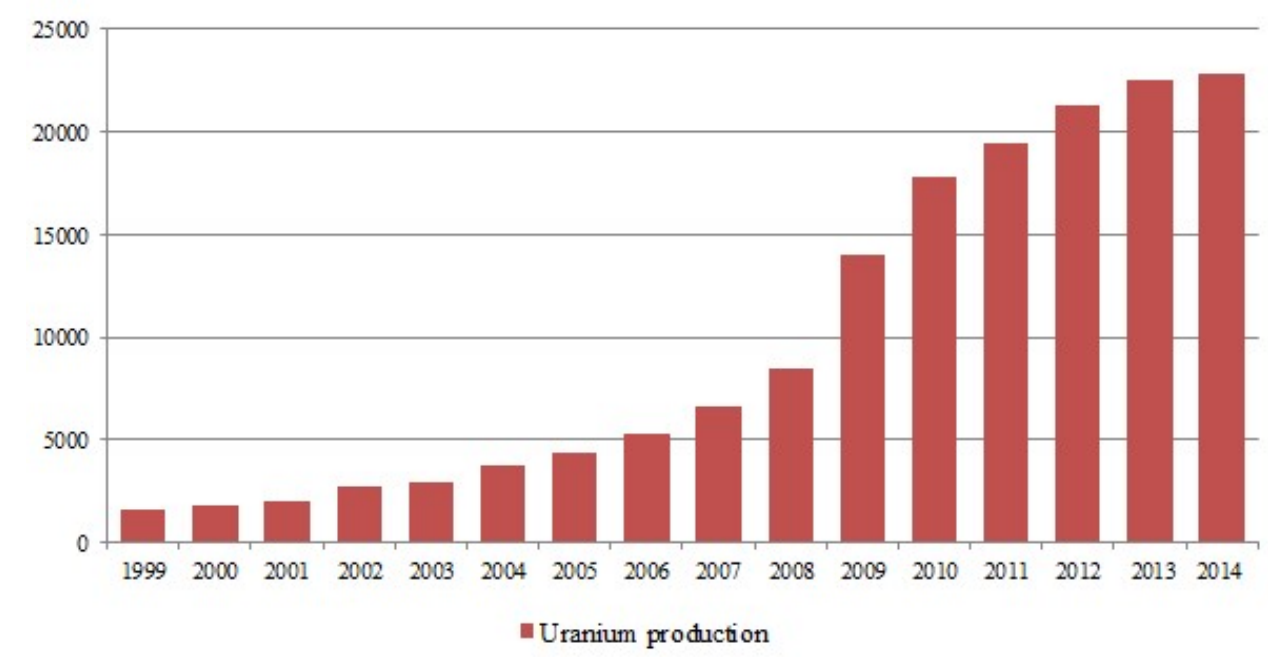

Fig. 14. Uranium production (Mt) [18] 


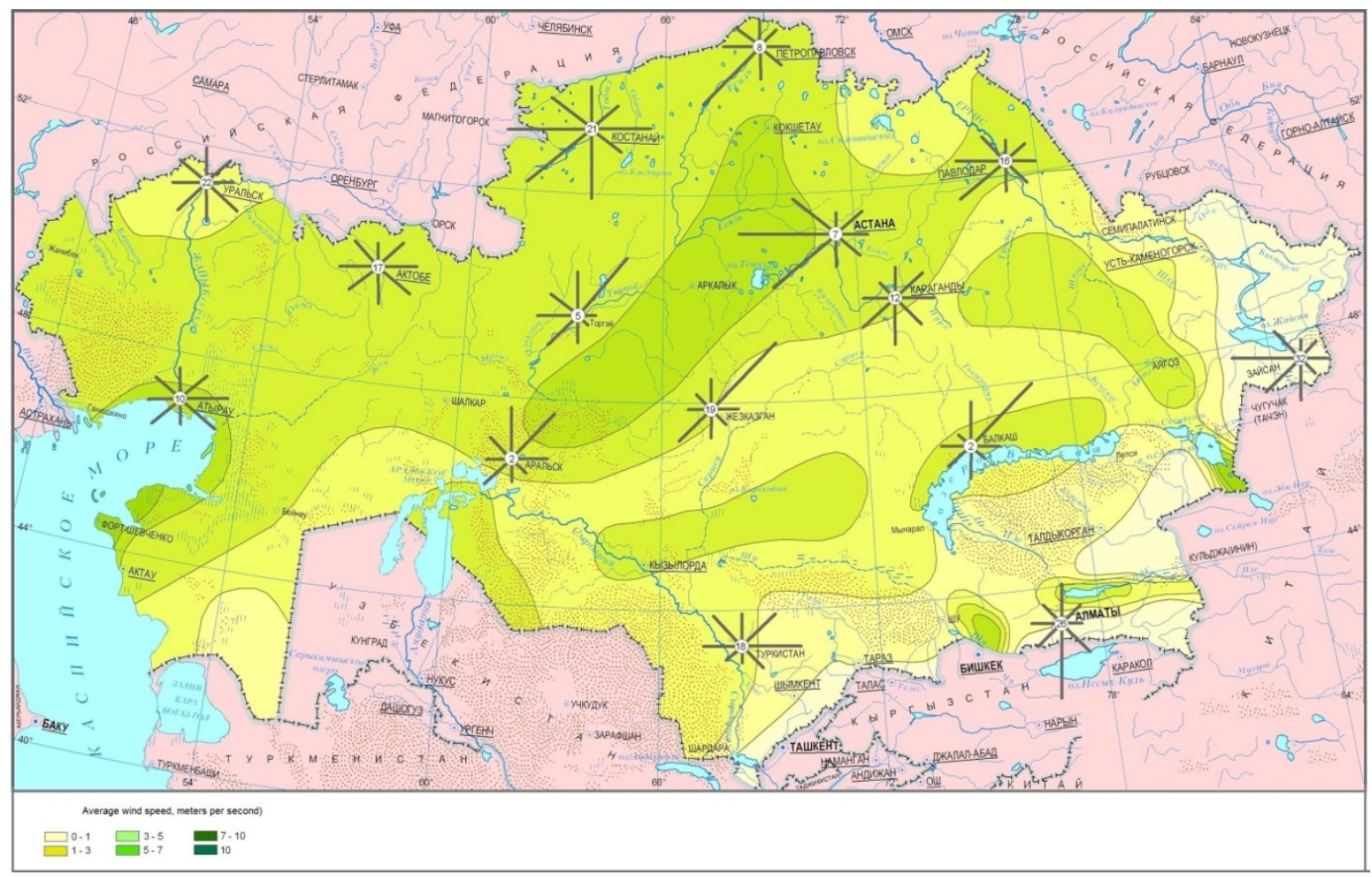

Fig. 15. Wind potential of Kazakhstan (m/s) [53]

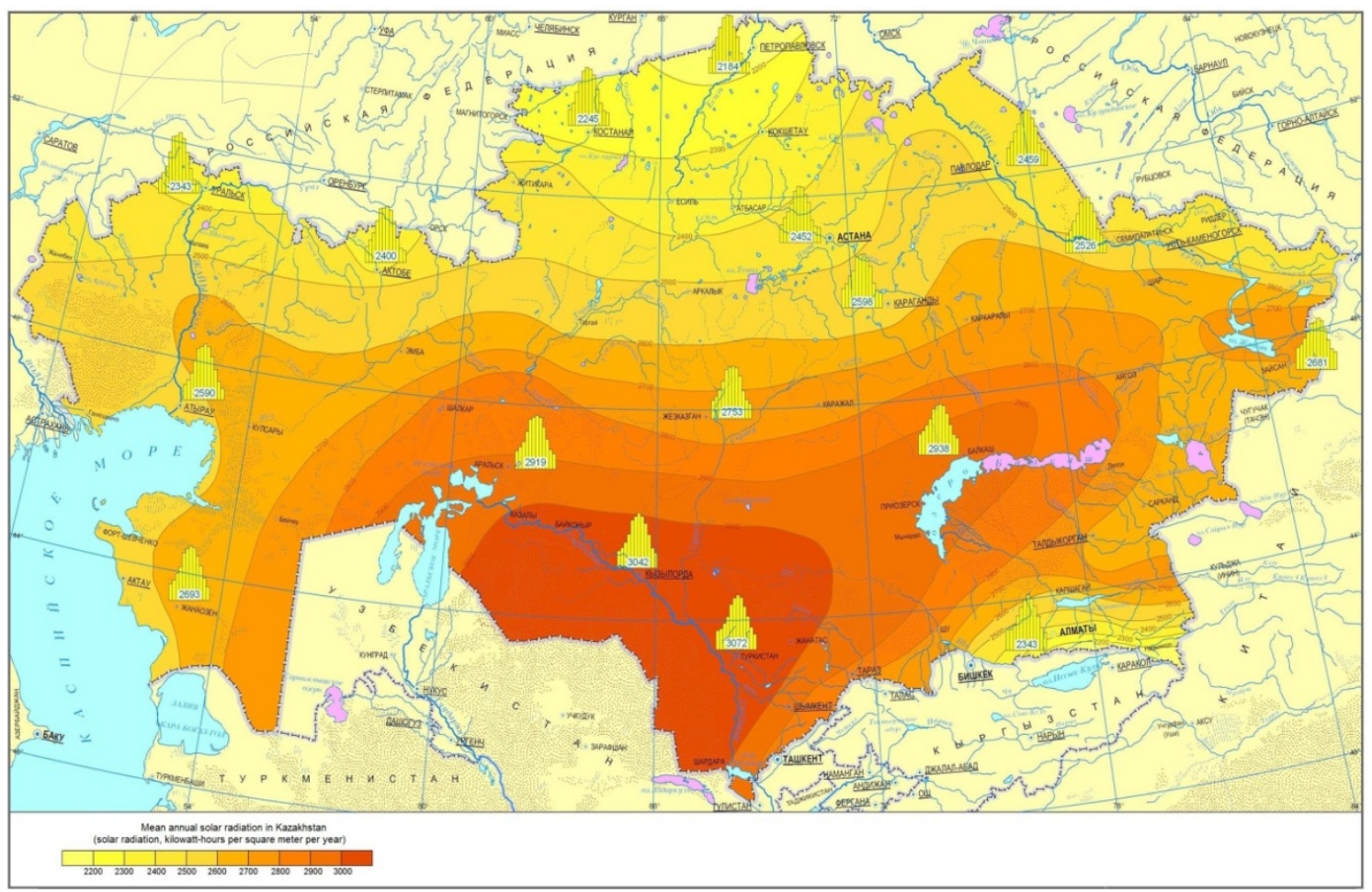

Fig. 16 Mean annual solar radiation in Kazakhstan (kWh/y) [53] 


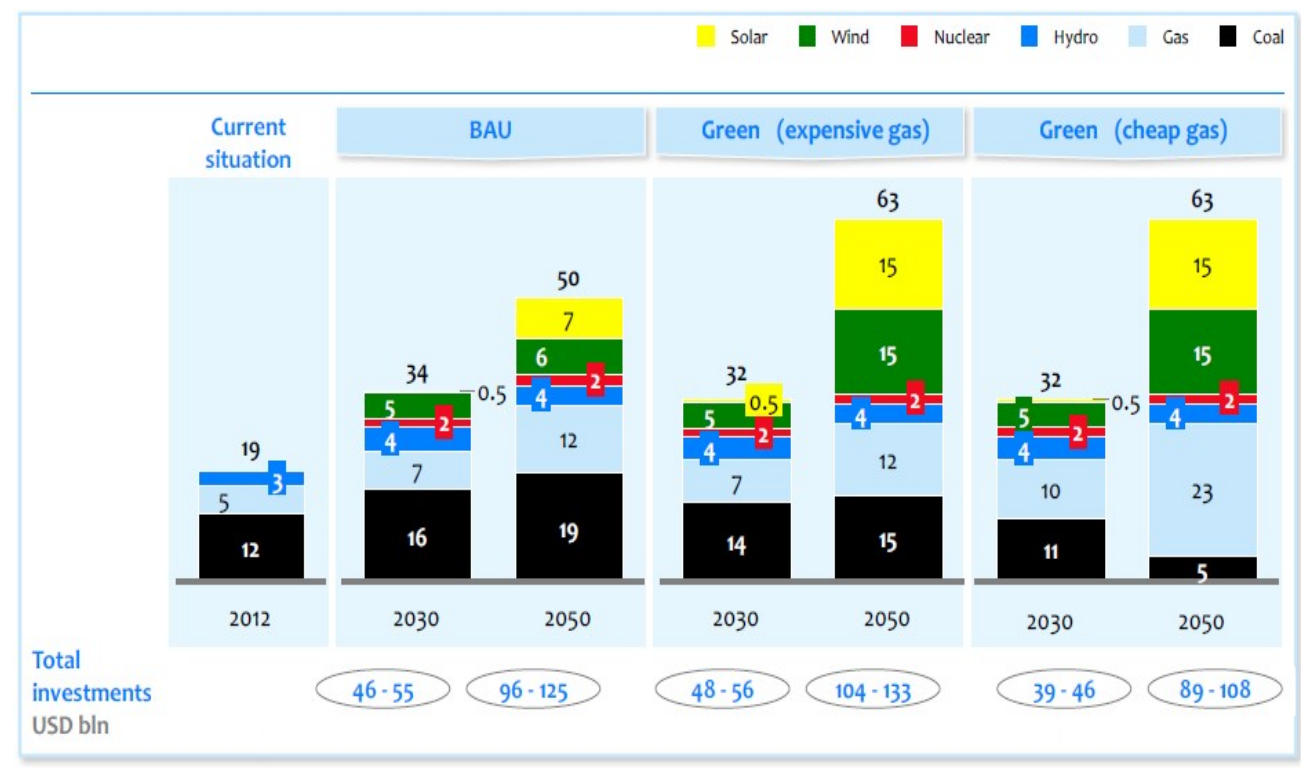

Fig. 17. Power sector installed capacity in scenarios (GW) [61]

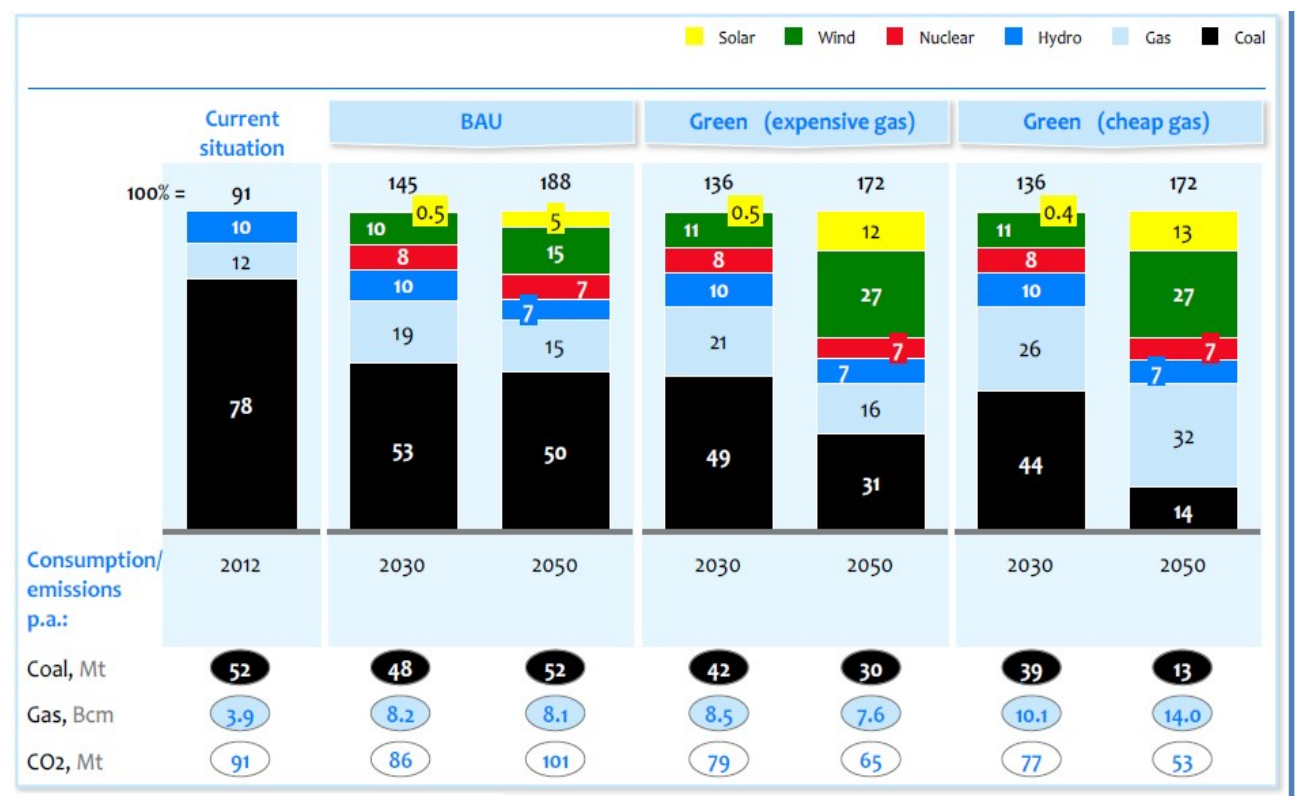

Fig. 18. Share in electricity generation profile by source (\%) [61] 
Table 1

Small hydropower projects in Kazakhstan [51]

\begin{tabular}{lccc}
\hline \multicolumn{1}{c}{ Regions } & Number of projects & $\begin{array}{c}\text { Projected installed } \\
\text { capacity (MW) }\end{array}$ & $\begin{array}{c}\text { Annual production } \\
\text { (GWh) }\end{array}$ \\
\hline East Kazakhstan & 68 & 349 & 1700 \\
Almaty province & n.a. & 1762 & 8700 \\
Southern Kazakhstan & 112 & 421 & 1800 \\
Zhambyl province & 77 & 175 & 700 \\
Total & 257 & 2707 & 12900 \\
\hline
\end{tabular}

Table 2

Prospective regions for wind power development in Kazakhstan [51]

\begin{tabular}{lcccc}
\hline $\begin{array}{c}\text { Location of potential } \\
\text { wind farms }\end{array}$ & Region & $\begin{array}{c}\text { No. wind } \\
\text { generators }\end{array}$ & $\begin{array}{c}\text { Projected installed } \\
\text { capacity [MW] }\end{array}$ & $\begin{array}{c}\text { Annual production } \\
\text { [billion kWh] }\end{array}$ \\
\hline Mangystau mountains & West & 8,000 & 210 & 0.4 \\
Peak Karatau & South & 7,800 & 190 & 0.23 \\
Chu-lli mountains & South & 6,800 & 180 & 0.27 \\
Mount Ulutau & Central & 3,400 & 90 & 0.13 \\
Yerementau mountains & Central & 2,100 & 50 & 0.01 \\
Mugojary mountains & West & 400 & 10 & 0.01 \\
Djungar gates & South & 1,100 & 200 & 0.66 \\
Total & & 29,600 & 930 & 1.71 \\
\hline
\end{tabular}

